\title{
A história de Frei Genebro segundo a estética do pormenor
}

\author{
Frei Genebro's story according to the aesthetics of the detail
}

\author{
Ana Marcia Alves Siqueira* \\ Universidade Federal do Ceará \\ Fortaleza, Ceará, Brasil
}

\begin{abstract}
Resumo: Eça de Queirós impulsionado por circunstancialismos histórico literários, como a apreciação da tradição medieval e a influência da pressão exercida por um espírito finissecular saturado da ciência e da civilização, cultivou, além do conto realista, contos inspirados no modelo tradicional da literatura oral com intuito pedagógico, aproximando-os da modernidade, através da inovação. Nessas composições, a estruturação tradicional passa a ser diluída em uma arquitetura narrativa apoiada no implícito, indiciado por diferentes recursos estilísticos e estratégias discursivas, como o uso do pormenor, da adjetivação sugestiva e de elementos da natureza de forma simbólica, efetivados por meio de uma fina ironia, que se relacionam, por sua vez, a uma temática recorrente na produção do autor: a oposição entre homem e natureza. A análise do conto "As Histórias. Frei Genebro" discute, pois, como a estratégia sutil que coloca em cena um elemento altamente significativo, nomeada como "estética do pormenor" (REIS, 2000), aliada ao modo de desenvolvimento dos recursos estéticos elencados revelam o objetivo crítico implícito pautado na reflexão sobre o homem e sua capacidade analítica interior. A argúcia crítica de Eça mira o passado para refletir sobre o homem - do passado e do presente - em suas idiossincrasias e fraquezas. A despeito da atemporalidade da questão, a recriação da matéria é sempre perpassada pelo espírito de seu tempo e pela ironia característica do autor, exigindo uma leitura atenta e ativa. Assim, nossa discussão a respeito do pormenor, da ironia e da análise interior do personagem apoiam-se em Barthes (2011), Reis (2000), Duarte (2006), Brait (2008) e Alves (2009).
\end{abstract}

Palavras-chave: Eça de Queirós. Conto. Estética do pormenor. Ironia.

\begin{abstract}
Eça de Queirós, driven by various historical and literary circumstances, such as the appreciation of the medieval tradition, and the influence of pressure exerted by a finissecular spirit saturated with science and civilization, cultivated, besides the realistic tale, also tales inspired by the traditional model of oral literature with pedagogical purpose, bringing them closer to modernity through innovation. In these compositions, the traditional structuring becomes diluted in a narrative architecture based on the implicit, indicted by different stylistic resources and discursive strategies, such as the use of detail, suggestive adjective and symbolic elements of nature, put into effect through a fine irony, which in turn relate to a recurring theme in the author's production: the opposition between man and nature. The analysis of the tale "As Histórias. Frei Genebro" discusses, therefore, how the subtle strategy that puts in place a highly significant element, named as "aesthetics of detail "(REIS, 2000), allied with the mode of development of the aesthetic resources listed reveal the implicit critical objective based on reflection about man and his inner analytical capacity. Eça's critical shrewdness targets the past to reflect on man - from past and present - in his idiosyncrasies and weaknesses. In spite of the timelessness of the issue, the recreation of matter is always passed by the spirit of its time and the author's characteristic irony, requiring careful and active reading. Thus, our discussion of character detail, irony, and inner analysis is supported by Barthes (2011), Reis (2000), Duarte (2006), Brait (2008), and Alves (2009).
\end{abstract}

Keywords: Eça de Queirós. Tale. Aesthetics of detail. Irony.

\footnotetext{
* Professora associada do Departamento de Literatura e do Programa de Pós-Graduação da Universidade Federal do Ceará- Fortaleza, Ceará, Brasil. E-mail: anaemar2003@yahoo.com.br.
} 


\section{O CONTO QUEIROSIANO ENTRE A TRADIÇÃO E A MODERNIDADE}

Publicados em revistas e jornais, os contos estão presentes ao longo de toda a produção de Eça de Queirós, considerado um dos principais escritores responsável pelo desenvolvimento do conto realista português. Embora o autor não tenha abandonado totalmente o enraizamento na tradição oral propalado pelo conto romântico e também utilize, algumas vezes, o recurso ao fantástico, esta produção contista está pautada no espírito crítico e na análise da sociedade mesmo quando o interesse pela Idade Média se desvela.

O traço característico destas incursões é a argúcia crítica de mirar o passado para refletir sobre o homem - do passado e do presente - em suas idiossincrasias e fraquezas. Estes aspectos têm desafiado estudiosos desta produção multifacetada do escritor, especialmente aquelas obras que, por seu afastamento dos preceitos da escola naturalista, foram denominadas por Carlos Reis (1997) como pertencentes à "deriva pós-naturalista". A inovação linguística mesclada ao uso de recursos estéticos variados, assim como de formas tradicionais e modernas, revela a complexidade da produção queirosiana, voltada para a análise da alma portuguesa em um contexto de busca de adequação à modernidade liberal capitalista.

O escritor impulsionado por circunstancialismos histórico literários diversos, como a apreciação da tradição medieval e antiga aliada à influência da pressão exercida por um espírito finissecular saturado da ciência e da civilização, cultivou, além do conto realista, contos inspirados no modelo tradicional da literatura oral com intuito pedagógico, aproximando-os da modernidade, através da inovação. Com Eça a estruturação tradicional passa a ser diluída em uma arquitetura narrativa apoiada no implícito, indiciado por diferentes recursos estilísticos e estratégias discursivas, como a ironia e a adjetivação incomum, cujo objetivo crítico está pautado na reflexão sobre o homem e suas circunstâncias. A despeito da atemporalidade da questão, a recriação da matéria é sempre perpassada pelo espírito de seu tempo e por seus ideais.

O conto "As Histórias. Frei Genebro", publicado na Gazeta de notícias em março de 1894, enquadra-se nesse contexto de relação intertextual com um relato à maneira de hagiografia da tradição franciscana. Luciana Stegagno Picchio (1997) localiza a fonte de inspiração num episódio de $A$ Vita di Frate Ginepro, conjunto de 15 capítulos publicados primeiramente de forma autônoma que depois incorporados como um apêndice da coletânea nomeada I Fioretti ${ }^{1}$. A pesquisadora esclarece que o fato levou, equivocadamente, Jaime Cortesão (1949) e, depois, o Dicionário de Eça de Queirós (1988) a registrarem o relato como parte desta coletânea. Por sua vez, Antônio Augusto Nery (2015), mais recentemente, realiza a análise intertextual entre o texto fonte e o conto queirosiano a partir da tradução brasileira de I Fioretti, organizada por Ildefonso Silveira e

\footnotetext{
${ }^{1}$ Segundo informa a autora, este é o nome genérico dado ao conjunto de textos sobre a vida de São Francisco de Assis e de seus companheiros que foi traduzido do latim para o toscano, por volta de 1380, como o: "Fioretti di San Francesco. Texto di língua. Edizione trata da quella di Firenze dell'anno 1718. Com aggiunte tratte dal Codice Fiorentino, Venezia: nella Tipografia Emiliana, 1853", Edição presente na Biblioteca de Lisboa.
} 
Orlando dos Reis e editada pela Editora Vozes, também subsidiado por informações sobre as biografias dos primeiros franciscanos constantes na obra de Maria Sticco que realiza "um interessante apanhado de exegeses franciscanas e de textos remetidos aos $I$ Fioretti" (NERY, 2015, p. 87).

Estes estudos partem de análises comparativas com a narrativa fonte para centrarem-se no texto de Eça. Cientes da dificuldade de não repetir questões já apresentadas, nossa contribuição para a discussão parte do argumento de Berardinelli (1997. p.167) sobre a recriação queirosiana de um relato popular no conto "O tesouro": o que importa é o modo como o escritor magistralmente construiu a narrativa preenchendo a estrutura inicial - "o esqueleto da história de proveito e exemplo" - nas diferentes feições artísticas.

Dessa forma, objetivamos discutir a inovação criativa da escrita queirosiana relacionada à concisão, à adjetivação incomum e ao uso de elementos da natureza de forma simbólica, efetivados por meio de uma fina ironia, que se relacionam, por sua vez, a uma temática recorrente na produção do autor: a oposição entre homem e natureza. A estratégia sutil que coloca em cena um elemento altamente significativo, nomeada como “estética do pormenor" (REIS, 2000), aliada ao modo de desenvolvimento dos recursos estéticos elencados revelam interessantes aspectos da produção de Eça de Queirós nesse final de século.

\section{CONCISÃO SUGESTIVA COMO ARCABOUÇO ESTRUTURAL}

O conto em análise constitui exemplo da opção pela tradição, mas de modo inovador, sutil, em que a composição do personagem e do sentido de sua prática caridosa se dá pela contraposição entre suas atitudes e elementos da natureza que vão funcionar como indícios da ironia presente, propondo um novo sentido para a narrativa e transformando-a em um interessante conto moderno que exige a construção a partir da leitura crítica, dos sentidos implícitos. Diferentemente da forma de caracterização do personagem realizada no texto por meio de descrições diretas e detalhadas, Eça de Queirós lança mão a outra forma de composição desta figura por meio do uso de elementos simbólicos, da narração irônica e da adjetivação sutil e instigante.

A defesa de uma concisão sugestiva no gênero foi exposta por Eça no prefácio ao livro Azulejos do Conde Arnoso:

\footnotetext{
No conto tudo precisa ser apontado num risco leve e sóbrio: das figuras deve-se ver apenas a linha flagrante e definidora que revela e fixa uma personalidade; dos sentimentos apenas o que caiba num olhar, ou numa dessas palavras que escapa dos lábios e traz todo o ser; da paisagem somente os longes, numa cor unida. Tu em boa hora seguiste fielmente esta poética, que é velhíssima, que já vem de Horácio (QUEIRÓS, 1994, p.70).
}

A construção de personagens e do ambiente é vista em conjunto com a construção artística da forma. Esse posicionamento se assemelha à concepção de Edgar Allan Poe (2011) que defende a unidade e brevidade de caracteres, de descrição e do tempo para que a escrita exerça certo efeito no leitor, Eça, por seu turno, defende uma organização 
interativa entre perfis de personagens e elementos narrativos buscando a concisão na linguagem, espelhada na arquitetura sintética do gênero, isto é, a construção de personagens e cenário obedece à construção do conto.

Em "As Histórias. Frei Genebro", essa arquitetura funciona como arcabouço de sustentação do sentido implícito presente. Ou seja, na poética de Eça, abreviado ao essencial, ao contrário de um cenário postiço, tal recurso semanticamente intensificado funciona como uma impressão, um sentido encoberto instaurado pela voz narrativa de maneira sutil, ora próxima e pautada em recursos da oralidade, ora mais distante e implícita favorecida pelo discurso indireto livre, como veremos adiante.

Assim, o primeiro parágrafo realiza a apresentação do protagonista que inicia pela ênfase na santidade de Francisco de Assis e na amizade que aproxima os dois, ou seja, além de relacionar comparativamente o comportamento de Frei Genebro ao santo, esta apresentação também oferece a localização espacial: "solidão das montanhas da Úlbria" e temporal da história (primeiras décadas do século XII), e confirma essa relação de proximidade. O parágrafo seguinte faz a descrição das qualidades do personagem, enfatiza sua prática penitencial por meio de comparações com elementos da natureza e o total domínio das virtudes evangélicas:

Pela abundância e perpetuidade da oração ele arrancava da sua alma as raízes mais miúdas do pecado, e tornava-a limpa e cândida como um desses celestes jardins em que o solo anda regado pelo Senhor, e onde só podem brotar açucenas. A sua penitência, durante vinte anos de claustro, fora tão dura e alta que já não temia o Tentador; e agora, só com o sacudir a manga do hábito, rechaçava as tentações, [...] como se fossem apenas moscas importunas. Benéfica e universal à maneira de um orvalho de Verão, a caridade não se derramava somente sobre as misérias do pobre, mas sobre as melancolias do rico. Na sua humilíssima humildade não se considerava nem igual dum verme. (QUEIRÓS, 2009, p. 273).

O início da narração parte da comparação entre elementos da natureza para discorrer sobre a prática penitencial do protagonista, caracterizando-o de modo sutil e delicado. A expressividade da prosa queirosiana é uma das características em evidência. $O$ trecho exemplifica a sugestividade no uso da linguagem, de forma sintética e precisa, e também a capacidade plástica do estilo queirosiano de inspirar leveza por meio das metáforas ligadas à natureza: a alma é como "um desses celestes jardins em que o solo anda regado pelo Senhor, e onde só podem brotar açucenas”, as tentações são afastadas "como se fossem apenas moscas importunas", a caridade do frei se derrama assim como "um orvalho de Verão".

Contudo, quando a narração enumera o efeito das ações do caridoso frei, capazes de amansar os barões bravios da Itália, de inspirar o reconhecimento e gratidão no papa Honório e até despertar o sorriso de anjos andarilhos que caminhavam pela terra à época, o exagero leva o leitor a perceber uma dissonância na situação - o excesso não passa despercebido em uma leitura atenta. Segundo Guerra Da Cal (1969), a linguagem queirosiana tem a capacidade de fazer ver a realidade disfarçada. Isto é, o sentido de real no conto problematiza o que é dito pelo narrador. Enquanto este apresenta uma série de características hiperbólicas do frei para atestar a sua santidade, o exagero desperta a atenção do leitor, indiciando a presença da ironia e da abertura do sentido da narração. 
Para a retórica, a ironia é o tropo relativo à disputa entre posições contrárias, por fundamentar-se em dizer algo, em certo contexto, para dar a entender o seu oposto, sem dizê-lo de fato, ou exprimir mais do que aparenta querer. $\mathrm{Na}$ qualidade de recurso linguístico a ironia tem sido estudada sob diferentes abordagens, de teor filosófico, psicanalítico, sociológico, literário, estilístico e linguístico-pragmático. Uma perspectiva produtiva para nossa discussão está relacionada, como apontamos, às marcas linguísticas, ou índices sutilmente distribuídos pelo narrador em sua enunciação. Assim, a capacidade sugestiva desse trecho leva o leitor a perceber um sentido implícito, a ler criticamente buscando desvendar o não dito. Segundo esclarece Beth Brait, a respeito da duplicidade irônica:

É essa estratégia analítica que permite visualizar uma sequência irônica como a construção em que existe a presença de um significante recobrindo dois significados, como acontece na mentira, mas integrada, obrigatoriamente, por um índice, cuja função é sinalizar a ironia, diferenciando-a da mentira. [...] Em outras palavras, o ironista [...] sinaliza de alguma maneira a mensagem para que o enunciatário reconheça e participe ativamente de sua 'nãosinceridade', de sua inversão semântica... (BRAIT, 2008, p.62).

A ironia queirosiana sinaliza a manipulação do sentido, o mascaramento da verdade, por meio de marcas ou indícios como incongruências, comportamentos dissonantes, exageros, repetições, uso de adjetivação incomum, oposições, exigindo uma leitura participativa e atenta. Esse trabalho estético realizado pelo autor pode ser exemplificado primeiramente pela estratégia de contrapor o exagero de qualidades de Genebro à simplicidade franciscana representada plasticamente na comparação com elementos da natureza. Por outro lado, a prática penitencial religiosa considera que não se pode descuidar, o mal habita a interioridade de cada um. Genebro, ao achar que já havia superado os perigos e armadilhas da imperfeição humana, torna-se vítima de si mesmo, pois, embora seja enfatizada a sua humildade, por não se considerar "nem igual a um verme", a vaidade (pecado contrário a esta virtude) está implícita na certeza de imunidade às tentações. De modo similar, a dedicação do frei à caridade acarretará o descuido a outras virtudes.

O episódio narrado para desenvolver esta ideia é a visita feita a Frei Egídio, companheiro de irmandade de Genebro há muito afastado em retiro na região por onde passaria no percurso de Spoleto para Terni. Ao caminhar pela floresta, longe da estrada, a natureza aprazível detalhadamente descrita e a água de um regato despertam nele a gratidão a Deus por tantas belezas, ao mesmo tempo, ao observar um porqueiro dormindo próximo pensou no perigo antes de seguir até a choupana do amigo: "Frei Genebro pensou nos lobos e lamentou o sono do pastor descuidado" (QUEIRÓS, 2009, p.274). Segundo Chevalier e Gheerbrant (1982, p.583), o simbolismo desses animais carnívoros, famosos pela selvageria e ferocidade, está relacionado no folclore europeu ao aspecto maligno e infernal; além disso, lobos são devoradores vorazes. Não por acaso esse animal também fora utilizado no conto “As Histórias. O tesouro", publicado na mesma Gazeta de Notícias em janeiro, dois meses antes deste em análise, com o qual também partilha o epíteto "As Histórias" e a inspiração em fonte medieval. 
Enquanto em "O tesouro" a comparação com "lobos" resume o estado emocional e valorativo dos irmãos Medranhos de maneira significativa: eles são selvagens, ferozes e capazes de tudo devido ao sofrimento causado pela miséria - informações que salientam a perda total da fraternidade entre eles -, em "Frei Genebro", a referência aos lobos carrega todo esse simbolismo de selvageria, mas sutilmente relacionada a um perigo não definido, exigindo a atenção do pastor adjetivado como "descuidado". Esse pormenor parece um detalhe desimportante, corriqueiro, porém, como parte da ação narrativa, conforme discutiremos adiante, funcionará como suporte para a crítica implícita.

Significativamente, assim que frei Egídio é encontrado moribundo em sua cabana e revela o desejo de comer um pedaço de porco, Genebro incorpora as características desse animal. Outro fato interessante, diz respeito ao protagonista ter perguntado ao irmão de fé sobre o que poderia fazer pelo corpo, já que manifesta a certeza de salvação da alma do amigo devido às práticas penitenciais praticadas ao longo da vida. Vejamos o trecho da transformação ocorrida com o protagonista após tranquilizar Egídio sobre a inexistência de pecado nesse desejo de contentar o corpo:

Pois sossegai, irmão querido, que bem sei como vos vou contentar!

E imediatamente, com os olhos a reluzir de caridade, de amor, agarrou o afiado podão que pousava sobre o muro da horta. Arregaçando as mangas do hábito, e mais ligeiro que um gamo, porque era aquele um serviço do Senhor, correu pela colina, até aos densos castanheiros onde encontrara o rebanho de porcos. E aí, andando sorrateiramente de tronco para tronco, surpreendeu um bacorinho desgarrado que fossava a bolota, desabou sobre ele, e, enquanto the sufocava o focinho e os gritos, decepou, com dois golpes certeiros do podão, a perna por onde o agarrara. Depois, com as mãos salpicadas de sangue, a perna do porco bem alta a pingar sangue, deixando a rês a arquejar numa poça de sangue, o piedoso homem galgou a colina, correu à cabana, gritou para dentro alegremente:

- Irmão Egídio, a peça de carne já o Senhor a deu! E eu, em Santa Maria dos Anjos, era bom cozinheiro. (QUEIRÓS, 2009, p. 276-278).

A vontade de realizar de imediato ao último desejo de um moribundo, sintomaticamente relacionado ao corpo, esconde um desejo, uma ambição motivadora de todas as ações de Genebro: alcançar o paraíso, assim, ele deixa de observar a prudência e a temperança, virtudes cardinais necessárias à prática religiosa. No trecho, o narrador contrapõe, por meio da escolha dos termos e seus significados, a bondade do personagem até então hiperbolicamente mencionada à atitude extremamente violenta, relacionando à ameaça de lobos aludidos anteriormente: "olhos a reluzir de caridade, de amor, agarrou o afiado podão". A esse primeiro estranhamento, segue-se a descrição do ataque sorrateiro e violento - "desabou sobre ele", "lhe sufocava o focinho" - em oposição a todas as ações positivas. Mais inusitado ainda é o fechamento da ação após a palavra sangue ser repetida três vezes para ressaltar a violência e a crueza da ação: "mãos salpicadas de sangue", perna do porco a "pingar sangue" e a pobre vítima "a arquejar numa poça de sangue" -, o personagem é qualificado como "o piedoso homem".

O trecho magistralmente construído parece desvelar a face sombria até então reprimida pelo frei, à maneira de um $M r$. Hyde 2 , ou um duplo animalesco que aflora repentinamente. Aqui

${ }^{2}$ Personagem do romance Strange case of Dr. Jekyll and Mr. Hyde (O estranho caso de Dr. Jekyll e Mr. Hyde), de Robert Louis Stevenson, publicado em 1886. 
parece mais irônica ainda a afirmação enunciada pelo narrador anteriormente: “... franciscano descalço e mal remendado que lhes ensinava a mansidão.” (QUEIRÓS, 2009, p.274).

A referência aos lobos, nessa perspectiva constitui um "pormenor" carregado semanticamente. Este processo é explicado por Carlos Reis "como categoria estética vocacionada para processos de inferência e de alegorização". Ou seja, apresenta-se como um detalhe, um pormenor significativo "porque remete indicialmente para o que depois se saberá e também para aquilo que apenas suspeitamos.” (REIS, 2002, p. 14).

Após a violenta ação praticada pelo franciscano, plasticamente ressaltada pela repetição do termo sangue, a menção ao animal toma a dimensão reveladora da faceta cruel e maligna presente na interioridade do personagem. O simbolismo da palavra emerge de modo a conotar o mal interior humano, as fraquezas e falhas inerentes à nossa condição que, por vaidade ou descuido não são percebidas. O detalhe salienta a importância do adjetivo "descuidado", projetando o que o frei viu como falha no porqueiro, como aquela existente nele mesmo. A palavra aponta para a necessidade de o personagem atentar para as próprias ações e escolhas, porque não exercia a vigilância sobre si, considerava-se imune às tentações devido aos anos de prática religiosa. Esse equívoco também se repete em relação ao frei Egídio, visto que Genebro se preocupou em ser caridoso com o corpo do franciscano ao considerar que "[...] pela alma bastante tendes vós feito na virtude desta solidão!" (QUEIRÓS, 2009, p. 276).

Enquanto no conto "O tesouro", os irmãos agem como lobos assassinando-se, o frei age como um lobo que sorrateiramente arranca a perna do bacorinho e o abandona em agonia. A insensibilidade para com a dor do animal é o vetor a contrapor natureza e ser humano, pois a fera real, ao devorar a vítima, não prolongaria o sofrimento desta. Enfim, nas duas narrativas a atribuição dos aspectos simbólicos e malignos desse animal aos personagens resultam em uma mordaz crítica às ações humanas em oposição às perfeições da natureza.

Conforme a narração, Genebro ignora totalmente os efeitos de suas ações sobre o animalzinho, só tem em mente a realização de seu intuito caridoso para com Egídio; por isso, após agir como um lobo traiçoeiro e brutal, ele é rápido como um gamo, galga a colina para alegremente preparar a peça de carne e servi-la. Ao longo de toda a preparação, a fina ironia característica do narrador repete com pequenas variações a palavra no cuidado de Genebro para com seu irmão de fé: "com zelo caridoso", "Tanta era sua caridade", "ternamente ajudou a sentar o velho" (QUEIRÓS, 2009, p. 277).

Esse excesso de zelo, igualmente desperta no moribundo ações mais voltadas para os aspectos corporais e instintivos do homem, pois, ele "tremia e se babava de gula". Por fim, para que o frade não se envergonhasse de "sua voracidade e tão carnal apetite", Genebro "mentia santamente" (QUEIRÓS, 2009, p. 277) que já havia se alimentado muito bem. Não se pode deixar de notar a contradição de a "caridade" - uma das virtudes evangélicas dominadas pelo frei ao longo de sua longa prática - ser a desencadeadora de ações pecaminosas: a ambição, a violência, a gula e a mentira. A primeira está bem diluída nas atitudes de Genebro exaltadas pela narração como caridosas; porém, essa prática constante, conforme dissemos, é fruto de sua ambição de alcançar o céu, independentemente das consequências de suas escolhas.

Novamente aflora a intertextualidade entre "as histórias" publicadas no início do ano de 1894 na Gazeta de Notícias, Genebro deseja conquistar o paraíso como um "tesouro", e, tal como um ambicioso, tudo faz para alcançá-lo sem medir os resultados. A soberba acompanha essa atitude, porque ele se considera livre das ameaças da tentação, do pecado; por isso se aproveita da fragilidade física e psicológica de frei Egídio para fazer mais uma "caridade", como se assim pudesse "galgar" os céus. 
O episódio é finalizado por meio do discurso indireto livre, em que as palavras de Egídio se misturam as do narrador: "Farto, consolado, Egídio deu um suspiro, recaiu no seu leito de folha seca. Que bem lhe fizera, que bem lhe fizera! O Senhor, na sua justiça, pagasse a seu irmão Genebro aquele pedaço de porco! Até sentia a alma mais rija para a temerosa jornada [...]" (QUEIRÓS, 2009, p. 277). O bem que o personagem fizera ao outro parece ressoar o mal que fizera ao porquinho. Assim, sem o saber, as palavras invocam a justiça divina para que aconteça o pagamento pela ação realizada.

O trecho salienta como o narrador do conto queirosiano exerce, de modo mais ou menos dissimulado, o seu poder. A dissimulação, associada à ironia e à linguagem altamente sugestiva, favorece o desenvolvimento de uma estrutura narrativa mais complexa, na qual o sentido irônico se organiza pelo conjunto de indícios analisados até aqui. Segundo Roland Barthes (1966, p.10), o indício é um elemento necessário à compreensão da história. Estabelecendo uma relação de natureza vertical e não linear, é uma unidade semântica que possibilita a cumplicidade entre o narrador e o seu leitor. Sua dimensão conotativa implica que a atividade interpretativa do leitor assuma um carácter mais dinâmico, por outro lado, pressupõe uma intromissão dissimulada por parte do narrador, que visa a, através do indício, favorecer uma leitura subjetiva sem comprometer a ilusão realista.

Assim, enquanto Genebro parte, a narração sutil deixa entrever a contradição da história, pois, o discurso indireto livre surge em meio ao discurso indireto:

Frei Genebro abençoou o velho, tomou o seu bordão, desceu a colina dos grandes carvalhos. Sob a fronde, para os lados onde andava o rebanho, a buzina do porqueiro ressoava agora num toque de alarme e de furor. Decerto acordara, descobrira o sen porco mutilado [...] Estugando o passo, Frei Genebro pensava quanto era magnânimo o Senhor em permitir que um homem, feito à sua imagem augusta, recebesse tão fácil consolação duma perna de cerdo assada entre duas pedras. (QUEIRÓS, 2009, p.278- grifo nosso)

A oração destacada pode ser o pensamento do frei enfatizado pela continuidade das reticências; entretanto, a narração prossegue, voltando ao registro indireto da voz narrativa, como se o protagonista não tivesse pensado naquilo, visto que "Estugando o passo", frei Genebro, segundo palavras do narrador, pensava em "quanto era magnânimo o Senhor". Essa pequena informação leva-nos a refletir: se os pensamentos do personagem não se relacionavam ao porquinho, por que ele havia apressado os passos? Essa escolha narrativa deixa em suspenso o conhecimento sobre a consciência ou preocupações do personagem, enquanto a narração prossegue com a enumeração das práticas caridosas e santas do frei igualmente de modo exagerado: "E prodigiosa foi desde esse dia a actividade de sua virtude." (QUEIRÓS, 2009, p. 278).

A história prossegue elencando a excelência das proezas caridosas de frei Genebro até a chegada de sua morte. Nesta segunda parte da história, o narrador apresenta o clímax do enredo, constituído pela descrição da recepção calorosa por parte de um anjo, da alma do franciscano, que a encaminha para o julgamento final materializado pela balança com dois pratos nos quais são pesadas as ações do frei. Embora o prato das virtudes e bondades seja o primeiro a pender representando todo seu percurso de penitências e ações caridosas, o outro, relativo às más ações, surpreendentemente, desce até deixar a balança em equilíbrio, causando grande pavor à alma de Genebro já enleada na certeza de desfrutar do Paraíso. O narrador ironicamente questiona qual ação fizera a "montanha de Boas Ações" parecer "um fumo mentiroso", antes de esclarecer: 
O prato, mais triste que a noite, parara - parara em pavoroso equilíbrio com o prato que rebrilhava. E os Serafins, Genebro, o Anjo que o trouxera, descobriram, no fundo daquele prato que inutilizava um Santo, um porco, um pobre porquinho com uma perna barbaramente cortada, arquejando, a morrer, numa poça de sangue... $\mathrm{O}$ animal mutilado pesava tanto na balança da justiça como a montanha luminosa de virtudes perfeitas! (QUEIRÓS, 2009, p. 282).

Assim, a mão de Deus, condena a alma de Genebro ao purgatório. Após o término da primeira parte da narração espraiar-se na descrição dos prodígios de caridade realizados pelo humilde Frei Genebro, esse desfecho quebra a expectativa de leitores desatentos aos indícios apontados anteriormente. Todavia, a descrição do conteúdo do prato relembra claramente a violência da ação contra o porquinho de maneira bárbara. A agonia do sofrimento e a poça de sangue se opõem às virtudes praticadas. A conclusão do julgamento sinaliza que a rotina de virtudes pregadas e realizadas não desculpa a crueldade contra um animal indefeso. Há uma crítica ao comodismo da rotina, das práticas desempenhadas sem uma reflexão, visto que Genebro não resistiu à tentação de ser caridoso com Egídio mesmo quando a consequência era o sofrimento de um pobre leitão.

De acordo com Nery (2015), este conto de Eça organiza-se por meio da intertextualidade paródica que realiza um cuidadoso jogo irônico ao inverter a mensagem de perdão e humildade, ensinada por Francisco da Assis, em condenação. O relato franciscano é um exempla, no qual Junípero, admoestado por Francisco, pede desculpa ao dono do animal de modo muito humilde e amoroso, resultando no perdão. Ao passo que a narrativa franciscana valoriza a humildade, o arrependimento, o perdão e a benevolência, o final do conto, segundo o pesquisador, é regido pelo “...'franciscanismo queirosiano', pois, o fato supostamente simples de ter causado sofrimento a um animal, foi suficiente para anular toda a vida de 'santidade' levada pelo protagonista" (NERY, 2015, p. 84). E finaliza explicando que a crítica de Eça é implacável, porque os modelos de perfeição (Jesus, Francisco de Assis) considerados jamais praticariam a violência para atender a um desejo carnal.

A ponte implícita para a época contemporânea do autor é a crítica à Igreja e aos cristãos que não vivenciam os ensinamos de amor e humildade destes modelos: "Não se obtêm o paraíso com práticas beatas, contraditórias e esvaziadas de significado. Entende-se assim uma crítica à beatice e a religião de fachada tão praticada em Portugal e criticada por Eça ao longo de toda a sua carreira." (NERY, 2015, p. 84-85).

\section{O PORMENOR COMO RECURSO DE ATUALIZAÇÃO INTERTEXTUAL}

Além dessa possibilidade de leitura, acrescentamos o desenvolvimento da análise desenvolvida até aqui a partir da linguagem sugestiva e da poética do pormenor. Esse jogo de sentidos exige uma percepção aguçada do leitor para o significado mais denso resultante da tessitura sutil e sugestiva que seduz e leva à reflexão.

Em várias obras de Eça, a natureza é um caminho que conduz a esse modelo de perfeição, mas de modo mais implícito. O final revela como Genebro não estava vigilante a respeito de suas ações e sentimentos em relação à alteridade. Enquanto as comparações com elementos da natureza qualificam sua prática penitencial - a alma limpa de pecados como raízes, as tentações como moscas abanadas - tudo estava tranquilo porque diz respeito a ele individualmente. Porém, quando a escolha recai sobre a ação envolvendo outros, o irmão Egídio, o porquinho, a atitude do frei revela o lado sombrio escondido em sua interioridade. Quando diz respeito a ele mesmo, 
Genebro não encontra obstáculos, porque abdicara de si, de seu corpo e necessidades em favor da ascese, do desejo de alcançar o paraíso. Porém, quando se trata do contentamento do outro, a escolha se complica, porque ele prefere privilegiar um seu igual em detrimento do mais fraco e diferente. Nesse aspecto, o simbolismo do pormenor emerge, salientando a necessidade de estar atento e vigilante ao aparecimento de lobos. O sentido implícito constitui uma advertência a todos, inclusive aos religiosos, por conseguinte, à Igreja, capaz de ações questionáveis em nome de um alegado bem maior.

Assim, na reflexão proposta pelo simbolismo utilizado, ser humano é deparar-se sempre com os aspectos sombrios e incontroláveis de nossa condição, por isso a utilização da palavra no plural. Ninguém escapa às ameaças internas, aos equívocos da própria consciência, especialmente em um contexto histórico de inconstâncias e grandes mudanças econômicas, sociais e científicas como o final de Oitocentos. A história de Genebro desvela o questionamento de Eça de Queirós sobre o pleno uso da capacidade racional e da consciência como meios seguros de o homem pautar as próprias ações. Esta leitura do pormenor proposta aqui se coaduna com a análise deste conto apresentada por Sílvio César dos Santos Alves (2009) no interessante artigo "Uma proposta de evolução estética na obra de Eça de Queirós", no qual discute a transformação desta questão ao longo da produção do autor.

Alves (2009) parte da proposição de Sérgio N. David (2007, p. 63) de que "educar a consciência" é uma das ideias presentes ao longo da produção queirosiana para discutir como $O$ Mandarim e, depois, "As Histórias. Frei Genebro", revelam a mudança de paradigma ao colocarem em pauta a descrença na concepção da filosofia positivista segundo a qual, em pleno domínio da razão, o homem agiria de acordo com sua essência, "o Bem absoluto". Conforme Alves (2009, p.7), n'O Mandarim, a consciência deixa de ser o supremo árbitro porque, ao final, apesar de o protagonista ter aprendido que matar é errado, ele chega à conclusão de que essa consciência não basta para impedir o mal comportamento, visto que prefere continuar rico apesar do sofrimento de culpa. Ou seja, mesmo sob o domínio da razão, a consciência pode ser ludibriada pelo desejo.

Após balizar o afastamento de Eça dos preceitos positivistas em relação às influências do contexto finissecular e da percepção da realidade sob uma perspectiva mais dialética que valoriza a imaginação e a razão, o pesquisador conclui que a narrativa sobre Frei Genebro "dá um duro golpe na crença no poder da razão e da consciência para salvaguardar o homem do 'perigo' e fazêlo agir virtuosamente" (ALVES, 2009, p.17). Segundo sua argumentação, a condenação ao purgatório não constitui uma crítica à concepção de santidade franciscana, em razão de concordar com Picchio (1997, p.310) de que este final está em consonância com os ideais franciscanos. O fundo moral não é o objetivo final, mas a reflexão sobre a ação em si, o engano da própria consciência do frei que, iludida pela vontade de realizar o último desejo do irmão de fé, esquecerase de avaliar criticamente o modo de realização, de pesar as consequências do ato praticado. $\mathrm{O}$ convencimento da licitude do desejo, o pretexto de fazer caridade, levara-o a praticar a violência contra o porquinho e a viver sem nem se preocupar com o ato. Somente durante o julgamento de sua alma, o personagem "descobre que não deveria confiar na própria consciência" (ALVES, p. 19). Segundo essa leitura, na busca de realização dos desejos, o homem é capaz de tudo, até de iludir sua consciência. De qualquer forma, sempre é punido pela crítica queirosiana.

Assim, Alves (2009) conclui considerando que o conto em análise revela a percepção aguçada de Eça sobre o drama humano diante do desejo, ao discutir aspectos da interioridade que ainda seriam colocados em pauta por Freud.

Em consonância, consideramos que Eça leva a discussão para uma perspectiva instigante, aprofundando alguns questionamentos presentes em Oitocentos. Ao suprimir a presença de Francisco de Assis em sua narrativa, Eça privilegia sutilmente a perspectiva do porquinho e 
problematiza a questão por colocar em discussão os limites das ações para alcançar um fim aparentemente bom. A fina ironia proposta pelo questionamento do narrador sobre a atitude que tanto pesava no prato dos pecados salienta que as ações importam tanto quanto o objetivo final. Entretanto, também consideramos que o conto não critica diretamente a ordem franciscana. Francisco de Assis foi o santo que difundiu a perspectiva de respeito e amor aos animais, assim como aos homens. Destarte, antes da morte, ao ouvir andorinhas cantando, o último pensamento de Genebro é justamente, uma conversa de Francisco com passarinhos que presenciara:

[...] sorrindo, recordou uma manhã, assim de silêncio e frescura, em que, andando com Francisco de Assis à beira do lago de Perusa, o mestre incomparável se detivera ante uma árvore cheia de pássaros e, fraternalmente, lhes recomendara que louvassem sempre o Senhor! "Meus irmãos, meus irmãos passarinhos, cantai bem o vosso Criador, que vos deu essa árvore para que nela habiteis, e toda esta limpa água para nela beber, e essas penas bem quentes para vos agasalharem, a vós e aos vossos filhinhos!" Depois, beijando humildemente a manga do monge que o amparava, Frei Genebro morreu. (QUEIRÓS, 2009, p. 280).

Esta menção pode ser lida como um pormenor sugestivo da atualização do contexto inicial, pois, a ausência do santo transfere para o julgamento pós-morte a necessidade de penitência para Genebro em razão da não percepção da falha grave. A conversa recordada indica como Francisco considerava os passarinhos, por analogia todos os animais, irmãos, criaturas filhas de Deus. Ou seja, um pormenor apresentado antes do julgamento final que já antecipa a perspectiva de condenação da atitude violenta contra o animal. Por sua vez, essa ausência da admoestação do santo, transfere para o personagem a responsabilidade de avaliação das próprias atitudes. Nessa perspectiva, o julgamento divino constitui uma imagem alegórica da necessidade de cada ser humano realizar um exame de consciência e pesar avaliativamente as próprias ações.

\section{CONSIDERAÇÕES FINAIS}

A reflexão apreciativa é deixada a cargo do leitor nesse instigante conto. Apoiada nos pormenores significativos analisados, especialmente a sugestão da existência de um lobo interior em cada um, e também nas escolhas insinuantes de comparações com elementos da natureza, nas oposições suscitadas - como ensinar a mansidão em oposição à ação com o porquinho - e na ausência de aprendizagem em vida, a leitura leva a transpor a distância temporal para refletir sobre a condição humana fora do contexto recriado.

Com efeito, a eficácia semântica da estética do pormenor na produção de Eça é explicada por Reis (2002, p. 22) como a construção de um cenário "em que o universal e o particular, o típico e o individual, o geral e o singular se casam harmoniosa e proporcionalmente". E conclui destacando a presença mais constante e significativa deste recurso: "Com o devir da escrita literária queirosiana, o pormenor será cada vez mais investido de propósitos simbólicos e alegóricos, cujo efeito final é a dimensão de transcendência que toda a grande literatura persegue." (REIS, 2002, p. 22)

O trabalho artístico realizado por Eça de Queirós, nessa narrativa, consegue esse efeito de transcendência e salienta a expressão complexa e dialógica de sua produção que "não apresenta lições prontas para serem recebidas passivamente"; ao contrário é construída como como arte que valoriza o leitor, como explica Lélia Parreira Duarte (DUARTE, 2006, p. 183) ao analisar o conto "Conde de Abranhos". 
O fato de Genebro ser encaminhado ao purgatório atualiza a mensagem franciscana de constante aprendizagem da humildade, como exemplificado no texto medieval. Por outro lado, coaduna-se com o objetivo de crítica, embora indireta, em consequência dos recursos estéticos utilizados: a paródia, a ironia e o pormenor. Esta escolha, porém, não é menos incisiva, visto que estes recursos levam à reflexão de forma mais artística e complexa, delineando o caráter dialógico da linguagem literária que, na lição de Bakhtin (1981), é sempre perpassada pela palavra do outro.

Ao propor que nem mesmo uma vida dedicada à caridade redime um crime cruel, se não houver o reconhecimento deste e o desejo de mudança, Eça de Queirós realiza uma arguta crítica ao homem à sociedade coetânea. Embora a consciência não seja suficiente para garantir a correção ética das escolhas, estar vigilante para esta fragilidade constitui um dever apontado pelo desfecho.

\section{REFERÊNCIAS}

ALVES, Sílvio César dos Santos. Uma proposta de evolução estética na obra de Eça de Queirós. CADERNOS DA FaEL. Vol. 2, nº. 6, p. 01-26, Set./Dez. de 2009. Disponível em: http://perseu.unig2001.com.br/cadernosdafael/vol2 num6/ARTIGO $\% 20$ SILVIO $\% 20 \mathrm{CADE}$ RNOS $\% 206 \% 20$ NO $\% 20$ FORMATO $\% 20 \mathrm{E} \% 20$ REVISADO.pdf

BAKHTIN, Mikhail. Problemas da poética de Dostoiévski. Trad. Paulo Bezerra. Rio de Janeiro: Forense Universitária, 1981.

BARTHES, Roland. Introduction à l'analyse structurale des récits. Communications. $\mathrm{n}^{\circ}$ 8, Paris: Seuil, 1966, p. 01-27.

BERARDINELLI, Cleonice. Um tesouro de segunda mão. In: MINÉ, Elza; CANIATO, Benilde J. Anais do III Encontro Internacional de Queirosianos. 150 Anos com Eça de Queirós. São Paulo: Centro de Estudos Portugueses: Área de Estudos Comparados de Literaturas de Língua Portuguesa/ FFLCH - USP, 1997, p.166-174.

BRAIT, Beth. Ironia em perspectiva polifônica. 2. ed. Campinas: Editora da Unicamp, 2008.

CHEVALIER, Jean; GHEERBRANT, Alain. Dictionnaire des symboles. Paris: Robert Laffont/ Jupiter, 1982.

CORTESÃO, Jaime. Eça de Queirós e a questão social. Lisboa: Seara Nova, 1949.

Dicionário de Eça de Queirós. Organização e coordenação de A. Campos Matos. Lisboa: Caminho 1988, s.v. Frei Genebro, p. 284.

DA CAL, Ernesto Guerra. Lingua e estilo de Eça de Queiróz. Tradução de Estella Glatt. Rio de Janeiro: Tempo Brasileiro, 1969.

DAVID, Sérgio Nazar. O século de Silvestre da Silva. Estudos Queirosianos. Rio de Janeiro: 7Letras, 2007.

DUARTE, Lélia P. A valorização do leitor na obra de Eça de Queirós (ou respondendo a Machado de Assis e a Fernando Pessoa). In: Ironia e bumor na literatura. Belo Horizonte: Editora PUC Minas; São Paulo: Alameda, 2006, p. 177-197, p.182.

NERY, Antônio Augusto. "Frei Genebro", um franciscano queirosiano. In: SANTOS, Giuliano L. Ito; VANZELLI, José C.; SOUSA, Márcio Jean F. (Orgs.). A obra de Eça de Queirós por leitores brasileiros: ensaios do Grupo Eça. São Paulo: Terracota Editora, 2015.

PICCHIO, Luciana Stegagno. Invenção e remake nos contos de Eça de Queirós: “Frei Genebro". In: MINÉ, Elza; CANIATO, Benilde J. Anais do III Encontro Internacional de Queirosianos. 150 Anos com Eça de Queirós. São Paulo: Centro de Estudos Portugueses: Área de Estudos Comparados de Literaturas de Língua Portuguesa/ FFLCH - USP, 1997, p.306-313.

POE, Edgar A.. A filosofia da composição. 2. ed. Prefácio de Pedro Süssekind e tradução de Léa Viveiros de Castro. Rio de Janeiro: 7Letras, 2011. 


\section{$\log$

QUEIRÓS, Eça de. Prefácio dos Azulejos do Conde de Arnoso. In: REIS, Carlos; RIBEIRO, Maria Aparecida. (Orgs.). História crítica da literatura portuguesa. Lisboa: Editorial Verbo, 1994, vol. VI, p.209-213.

QUEIRÓS, Eça. Contos I. Edição Crítica de Marie Hèlene Piwnik. Lisboa: Casa da MoedaImprensa Nacional, 2009.

REIS, Carlos. Eça de Queirós Cônsul de Portugal à Paris 1888 - 1900. Paris: Centre Culturel Calouste Gulbenkian - Portugal, 1997.

REIS, Carlos. Eça de Queirós e a estética do pormenor. In: REIS, C. Et al. Actas do Congresso de Estudos Queirosianos. IV Congresso Internacional de Queirosianos. Coimbra: Almedina, 2002, p. 13-29.

Recebido em: 28/11/2019

Aprovado em: 07/12/2019

Publicado em: 19/12/2019 